\title{
ECONOMIC ANALYSIS OF CORIANDER SEED MARKETING IN TAMIL NADU
}

\section{RAJESH. R}

Professor of Agricultural Economics, Department of Food Policy, Tamil Nadu Agricultural University, Madurai, India

\begin{abstract}
In this study, an attempt has been made to estimate economics of coriander seed marketing in Tamil Nadu. The study was conducted with a sample size of ninety coriander farmers and thirty intermediaries. In addition, five coriander grading units were selected randomly in the study area, to estimate economics of establishment of coriander seed grading unit. Price spread was estimated to identify profitable marketing channel and investment analyses like NPV, BC Ratio, IRR and Break Even Point were estimated to analyse economics of establishment of coriander seed grading unit. Price spread estimated for third channel (Farmer-Wholesaler-Retailer-Consumer) was 33.15 per cent and identified as best marketing channel. But it was observed that, majority of farmers were forced to sell their product immediately through other channels due to financial crisis and pressure to meet out family necessary expenditures. It was suggested that establishment of coriander seed grading unit collectively by corianders producers in major coriander cultivating areas, would increase the welfare of farmers.
\end{abstract}

KEYWORDS: Price spread, IRR and Break Even Point

Received: May 28, 2020; Accepted: Jun 18, 2020; Published: Jul 02, 2020; Paper Id.: IJASRAUG202008

\section{INTRODUCTION}

India is often referred as the "spice hub of the world", because of its larger production consumption in the world. About 80 per cent of the world total coriander seed is produced in India. In the spices, coriander plays important role in international trade only five to ten per cent of total production of coriander is exported from India, because coriander is an important spice crop having a prime position in flavoring Indian food. (Farooqi et al., 2005). In Tamilnadu, concentrated pockets of coriander growing districts are Thoothukudi, Virudhunagar, Ramanathapuram and Coimbatore. Virudhunagar is the Major coriander seed market in Tamil Nadu. Local coriander is preferred for consumption due pungent, golden colour, well dried and matured without shrivels qualities. Farmers are slowly shifting their coriander cultivation to other crops due to price fluctuation and irregular and minimum rainfall. In this background, the project was formulated to study economics of coriander seed marketing and establishment of coriander grading centerin southern Tamil Nadu, with the following specific objectives: (1)to identify the existing marketing channels in coriander seed marketing; (2)to quantify the price spread of various marketing channels in coriander seed marketing; (3)to estimate economics of the establishment of coriander seed grading unit and (4)to examine the problems affecting the coriander seed marketing and grading and suggest possible measures.

\section{METHODOLOGY}

In Tamil Nadu, major coriander cultivating districts are Thhthukudi, Virudhunagar, Ramnathapuram, Madurai and Sivagangai, which account for 71.40 per cent to total area under coriander in Tamil Nadu. Among the districts, Thoothukudi, Virudhunagar and Maduraidistricts were purposively selected for the study. Total farmers sample size was ninety, from which, thirty coriander farmers were selected randomly from each district. Then, thirty market 
intermediaries were selected at ten intermediaries from each district, randomly. In addition, five coriander grading units were selected randomly in the study area to estimate economics of establishment of coriander seed grading unit. Price spread was estimated to identify profitable marketing channel, and investment analyses like NPV, BC Ratio, IRR and Break Even Point were estimated to analyse economics of establishment of coriander seed grading unit.

\section{RESULTS AND CONCLUSIONS}

\subsection{Marketing Channels}

It was inferred from the study that three marketing channels in coriander seed marketing were identified in the study area, as given below:

- Channel 1: Farmer-Local trader-Wholesaler-Retailer-Consumer

- Channel 2: Farmer-Commission agent-Wholesaler-Retailer-Consumer

- Channel 3: Farmer-Wholesaler-Retailer-Consumer

In these marketing channels, majority of farmers used first and second channel accounting for ninety per cent of total sample size. These farmers represented marginal and small farmers, and they sold the products immediately after harvest without grading. It was interested to observe that some of medium and large farmers stored the product and graded the product and sold to the wholesalers with better price. The reasons for this behavior are discussed in the later section.

\subsection{Price Spread Analysis}

Further, the price spread of various marketing channels in coriander seed marketing in the study area was worked out, and the details are furnished in table 1 .

Table 1: Price Spread Analysis in Coriander Seed Marketing in the Study Area (Rs per Qtl)

\begin{tabular}{|c|c|c|c|c|c|c|c|}
\hline \multirow[t]{2}{*}{ S.No } & \multirow[t]{2}{*}{ Particulars } & \multicolumn{2}{|c|}{ Channel 1} & \multicolumn{2}{|c|}{ Channel 2} & \multicolumn{2}{|c|}{ Channel 3} \\
\hline & & Amount & $\%$ & Amount & $\%$ & Amount & $\%$ \\
\hline \multirow[t]{4}{*}{1} & Farmer & & & & & & \\
\hline & marketing cost & 310 & 3.36 & 641 & 6.53 & 393 & 4.00 \\
\hline & Net price received by farmer & 5740 & 62.26 & 6060 & 61.77 & 6558 & 66.85 \\
\hline & Selling price & 6050 & 65.62 & 6700 & 68.30 & 6950 & 70.85 \\
\hline \multirow[t]{4}{*}{2} & $\begin{array}{l}\text { local trader / commission } \\
\text { agent }\end{array}$ & & & & & & \\
\hline & marketing cost & 88 & 0.95 & 128 & 1.30 & & \\
\hline & marketing Margin & 410 & 4.45 & 560 & 5.71 & & \\
\hline & Selling price & 6548 & 71.01 & 7120 & 72.57 & & \\
\hline \multirow[t]{4}{*}{3} & wholesaler & & & & & & \\
\hline & marketing cost & 543 & 5.88 & 543 & 5.54 & 549 & 5.59 \\
\hline & marketing Margin & 1160 & 12.58 & 1245 & 12.69 & 1210 & 12.34 \\
\hline & Selling price & 8250 & 89.48 & 8908 & 90.80 & 8709 & 88.78 \\
\hline \multirow[t]{3}{*}{4} & Retailer & & & & & & \\
\hline & marketing cost & 150 & 1.63 & 145 & 1.48 & 160 & 1.63 \\
\hline & marketing Margin & 820 & 8.89 & 895 & 9.12 & 940 & 9.58 \\
\hline \multirow[t]{2}{*}{5} & Consumer & 9220 & 100.00 & 9948 & 100.00 & 9809 & 100.00 \\
\hline & Price spread (\%) & \multicolumn{2}{|c|}{37.74} & \multicolumn{2}{|c|}{39.09} & \multicolumn{2}{|c|}{33.15} \\
\hline
\end{tabular}


Note:

- Channel 1: Farmer- Local trader-Wholesaler-Retailer-Consumer

- Channel 2: Farmer- Commission agent-Wholesaler-Retailer-Consumer

- Channel 3: Farmer-Wholesaler-Retailer-Consumer

It was observed that third marketing channel was identified as the best marketing channel among prevailed marketing channels in coriander seed marketing, in the study area. It was estimated that price spread for that channel was 33.15 per cent. Farmers graded and sold coriander seed directly to wholesalers, after storing the product or collectively sold to them. It paved the way for reducing marketing cost to 11.23 percent to consumer's price. But, it was observed that majority of farmers were forced to sell their product immediately through first or second channel due to financial crisis and pressure to meet out family necessary expenditures. Another important observation was that the farmers were selling the product without grading, and completed to sell the products at lower price to the local traders.

\subsection{Economics of Establishment of Coriander Seed Destoning and Grading Unit}

Economics of Establishment of Coriander seed Destoning and Grading Unit was estimated and discussed in the table 2. The data were obtained from the sample Coriander seed Destoning and Grading Units, and necessary cross verifications were undertaken to work out the economics of establishment of the units. It was inferred that annual grading cost was about Rs.5.09 lakhs for establishment of coriander seed destoning and grading unit (for 300 days @ 40 Qtls/day).

Table 2: Economics of Establishment of Coriander seed Destoning and Grading Unit (for 300 days @ 40 Qtls/day) (Rs in lakhs)

\begin{tabular}{|c|c|c|}
\hline S.No & Particulars & Amount \\
\hline $\mathbf{I}$ & Capital Investment & \\
\hline 1 & land and building & 3.00 \\
\hline 2 & Destoner cum Grader cum aspirator @ 5 Qtls/hour & 1.00 \\
\hline 3 & weighing machine and accessories & 0.15 \\
\hline 4 & Installation & 0.07 \\
\hline \multirow[t]{3}{*}{5} & Office furniture & 0.03 \\
\hline & Sub total & 4.25 \\
\hline & Share of establishment cost & 0.28 \\
\hline II & Annual Fixed cost & \\
\hline 1 & Permanent staff@5000/month & 0.60 \\
\hline 2 & depreciation & 0.08 \\
\hline 3 & Interest on fixed capital & 0.11 \\
\hline \multirow[t]{2}{*}{4} & maintenance cost & 0.06 \\
\hline & Sub total & 0.85 \\
\hline III & Annual Variable cost & \\
\hline 1 & labour charge & 3.00 \\
\hline 2 & electricity charges & 0.28 \\
\hline 3 & Local tax \& mis Expenses & 0.32 \\
\hline 4 & wastage cost & 0.14 \\
\hline \multirow[t]{2}{*}{5} & interest on working cost & 0.22 \\
\hline & Sub total & 3.96 \\
\hline \multirow[t]{2}{*}{ IV } & Annual grading cost & 5.09 \\
\hline & variable grading cost/Qtl & 33.00 \\
\hline
\end{tabular}

Further, it was found from table 3 that profit/year Rs 2.11 lakhs in the establishment of coriander seed destoning 
and grading unit. The Internal Rate of Return for the investment in the establishment this unit was 29.07 per cent, and found economically feasible. It was observed that grading the product before sales paved the better revenue to the farmers. The traders preferred the quality product and were ready to premium price to the graded product.

Table 3: Economics of Establishment of Coriander seed Destoning and Grading Unit (for 300 days @ 40 Qtls/day)

\begin{tabular}{|l|l|c|}
\hline S.No & \multicolumn{1}{|c|}{ Particulars } & Amount \\
\hline 1 & Annual grading cost (Rs in lakhs) & 5.09 \\
\hline 2 & Grading quantity (40 Qtls/day)(lakh Qtls) & 0.12 \\
\hline 3 & Grading Charge (Rs /Qtl) & 60.00 \\
\hline 4 & Gross income/year (Rs in lakhs) & 7.20 \\
\hline 5 & Profit/year (Rs in lakhs) & 2.11 \\
\hline 6 & Cost of grading ( Rs/Qtl) & 42.42 \\
\hline 7 & Profit(Rs/Qtl) & 17.58 \\
\hline 8 & NPV @ 10\% (Rs in Lakhs) & 4.19 \\
\hline 9 & BC Ratio (\%) & 1.10 \\
\hline 10 & IRR (\%) & 29.07 \\
\hline 11 & Break Even Point (BEP) (Qtls) & 3141.49 \\
\hline
\end{tabular}

It was observed that cost of grading was Rs.42.42/Quintal in the collectively established grading unit, whereas it was Rs.100/Quintal in private grading units in the study area. The grading capacity was fixed was 12,000 quintals/year, which was four times better than breakeven point of the proposed unit. Reasonable subsidy is available from State government marketing division to motivate the farmers, towards quality marketing and reasonable income to farmers in the study area.

\section{CONCLUSIONS AND SUGGESTIONS}

The major problems affecting the coriander seed marketing were identified as(i)no remunerative price;(ii) inadequate storage facility;(iii) high transportation cost and (iv) absence of grading. Based on the study results, it has been suggested for the establishment of coriander seed grading units, collectively by coriander producers in major coriander cultivating areas and formation of Coriander Producers Company to facilitate good marketing environment with advanced marketing infrastructures in the study area, by bringing together producers and traders in one place by minimizing marketing cost and increasing the income of farmers, and to supply quality products at reasonable price to consumers.

\section{REFERENCES}

1. Farooqi, A. A., Sreeramu, B. S. and Srinivasappa, K. N., 2005, Cultivation of Spice

2. Crops. Universities Press (India) Private Limited, Hyderabad

3. Kumawat, R.C., Meena, P.C., 2005, Growth and instability in area, production and yield of major spices crops in Rajasthan visà-vis India. Journal of Spices and Aromatic crops, 14 (2); 102-111

4. Anantha, Venkata Prasad Babu and Sidana, Baljinder Kaur (2019). Economic analysis of export performance of major Indian spices. International Research. Journal. Agricultural Economics. \&Statistics. 10 (2) : 302-310. 